\title{
THE IMPACT OF BOMBAY'S TEXTILE INDUSTRY ON WORK OF WOMEN FROM SUGAO VILLAGE
}

\author{
by HEMALATA C. DANDEKAR
}

Assistant Professor of Urban Planning. University of Michigan, Ann Arbot, USA

\begin{abstract}
$\mathrm{T}$ he cotton textile industry in India, well established by 1879 , was predominantly located in the city of Bombay.' L.abour for this industry was primarily drawn from the Konkan and Deccan region of Maharashtra ${ }^{2}$ and this migration of workers greatly affected the lives of men and women from these regions. Although now in dedine. ${ }^{3}$ the textilc industry continues to be a major force in the lives of rural people from regions such as Satara District in the Deccan hinterland of Bombay. This is clearly reflected in the study of a representative village, here called Sugao, on the Deccan Platean in Satara District. ${ }^{4}$ Sugao is over $150 \mathrm{~km}$ from Bombay, a journey of more than 10 back-breaking hours on the Bombay State Transport buses (see Fig. 1).
\end{abstract}

\section{Work in Bombay}

A trickle of Sugao men had migrated to Bombay at the turn of the century, drawn to newly available jobs as dock workers in the port. ${ }^{5}$ Most of these men were from higher caste Maratha families (Table 1 ) $^{6}$ which migrated to the city seasonally during the 'rabi' (second, dry season) crop while their women remained behind in Sugao, working within the joint or extended family primarily in agriculture (Table 2$)^{7}$ By 1942 , as can be seen in Table 3 , the main occupation of the Sugao male migrant to Bombay was that of textile mill worker. By then, migration had ceased being seasonal as jobs in the mills became more difficult to obtain. Men migrated year-long for all their productive, adult work years, returning to their families once or twice a year for vacations. Since then, over the years, men from the village have bccome better educated, developed more contacts with people in Bombay, and have been able to find better, more diversified work in the city. Thus jobs in the textile industry have been an avenue for upward mobility for village men. In addition, work in the textile mills has remained a mairstay occupation for Sugao migrants despite having dropped from 66 per cent of all migrants in 1942 to 41 per cent in 1977. In real numbers there were more men from Sugao in the textile industry in 1977 (195) than in 1942 (135).

In contrast to the above, however, the flow of Sugao women to Bombay for work has remained very restricted. In 1942 only seven women worked in the city: most had what are traditionally considered low status jobs such as working as domestic servants or serving meals to workers. This situation has not changed significantly with time. Out of the 111 adult 


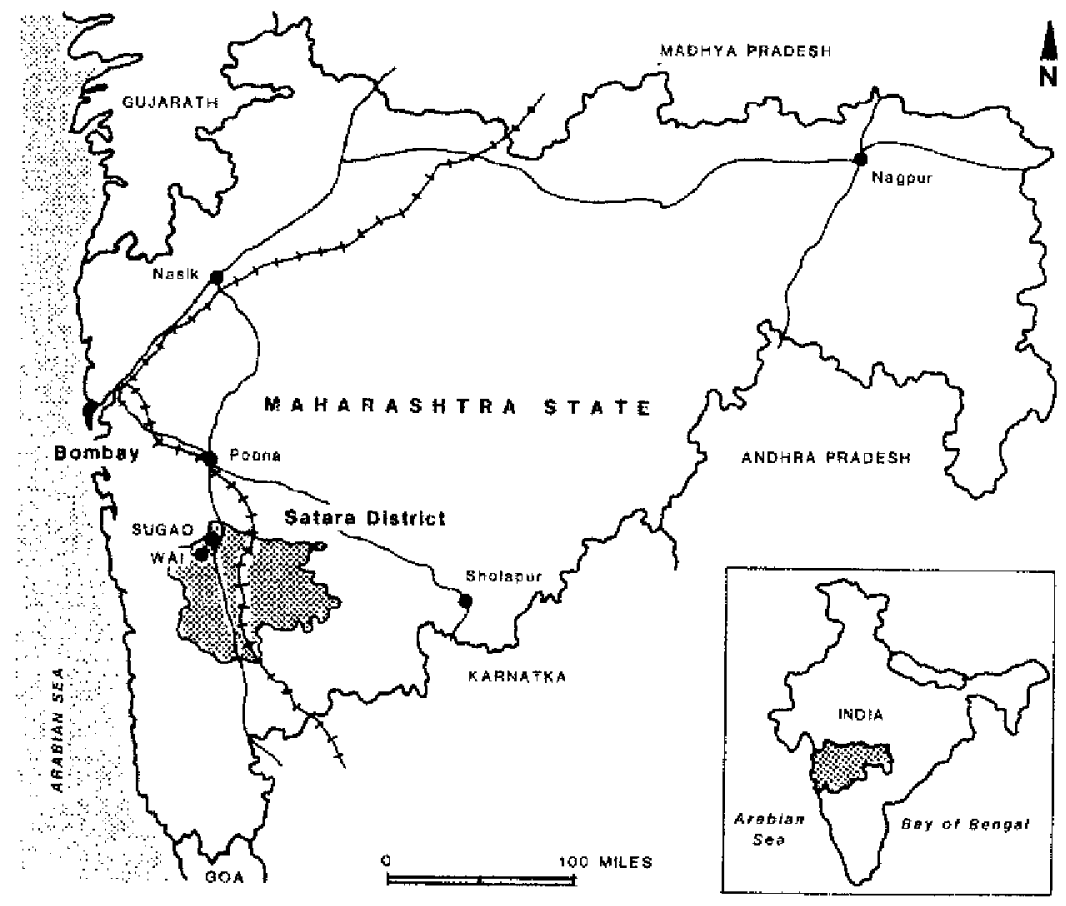

Fig. I The locations of Bombay and Sugao in the State of Maharashtra

women (over 16 years of age) who lived out of Sugao in 1977, only 11 were in an earning occupation, of whom four were domestics in the meals catering business. Most women who do move out of the village do so with their husbands, as housewives. Some of the cultural as well as economic reasons for this characteristic of femalc migration are described in this paper.

Of the women who have migrated to Bombay, only a handful either moved alone or are earning an independent living in the city. Case study information on women who have moved to the city alone since 1942 indicates that these have tended to be destitute, left widowed with children to support and owning little or no land (which continues to be the primary productive asset in Sugao). Although some jobs are now available for Sugao women having the required education, the traditional occupation for the illiterate, destitute woman forced to move to the city is that of a domestic servant. With luck and resourcefulness, she can hope to build up a khanaval (meal-serving establishment) that caters to factory workers.

An example of such a survival is that of a high school teacher in Sugao today, of the Dhangar or weaver caste who was raised by his mother in Bombay. Anecdotal information and field notes of previous researchers ${ }^{8}$ relate that his mother, left with few resources to support her upon the death of her husband, had sequentially become the mistress of two or three prominent Maratha caste leaders of Sugao. To become a mistress of someone with resources and status is one avenue to survival in the village for a destitute woman. But it is a precarious one. This woman had been divested of her meagre remaining resources by these men and had fled to Bombay with her sons, managing to survive first as a domestic servant and later by establishing her own khanaval business.

Such precedents partly explain why the business of running a khanaval, one of the few avenues open to women to survive independently, is held in low esteem. Sugao people, both men and women, but particularly women, will express opinions about who the few 'good' 
1Ak1.t. 1 Caste distribution of Sugao population in Sugao and outside (percentages)

\begin{tabular}{lrrrrrr}
\hline & \multicolumn{2}{c}{1942} & \multicolumn{2}{c}{1958} & \multicolumn{2}{c}{1977} \\
Caste & Sugao & Outorde & Sugao & Outside & Sugao & Outside \\
\hline Marathas & 67 & 57 & 68 & 59 & 70 & 64 \\
Dhangars & 10 & 8 & 8 & 10 & 7 & 9 \\
Artisans & 11 & 11 & 10 & 9 & 11 & 9 \\
neo-Buddhists & 9 & 20 & 9 & 18 & 6 & 14 \\
Others & 3 & 4 & 5 & 4 & 6 & 4 \\
\hline Totals & 100 & 100 & 100 & 100 & 100 & 100 \\
\hline Number of persons & 1621 & 271 & 2040 & 488 & 2583 & 737 \\
\hline
\end{tabular}

Data for Tables 1, 2 and 3 from full census surveys of households in Sugan in 1942-43 and 1958-59 by the Gokbale Institute of Politis and Economics. Poona and a similar survey of the village by the author in 1976-77.

TAв1 1: 2 Adult male migration and family type

\begin{tabular}{|c|c|c|c|}
\hline & $\begin{array}{c}1942 \\
\%\end{array}$ & $\begin{array}{c}1958 \\
96\end{array}$ & $\begin{array}{c}1977 \\
\%\end{array}$ \\
\hline \multicolumn{4}{|l|}{ Family $T_{y p e s}$} \\
\hline \multicolumn{4}{|l|}{ 1. Joint all adult males } \\
\hline lising in Sugao & 19.3 & 14.1 & 13.2 \\
\hline \multirow{2}{*}{\multicolumn{4}{|c|}{ 2. Joint at least one aduit }} \\
\hline & 26 & 26.7 & 33.1 \\
\hline \multicolumn{4}{|l|}{ 3. Joint all adult } \\
\hline males outside Sugao & 6.7 & 6.2 & 6.3 \\
\hline Total joint familes & 52 & 47 & 52.6 \\
\hline \multicolumn{4}{|l|}{ 4. Nuclear-one adult male: } \\
\hline in sugao & 30.9 & 31.0 & 27.2 \\
\hline \multicolumn{4}{|l|}{ 5. Nuclear-No adult male } \\
\hline in Sagao & 8.9 & 13.1 & 13.4 \\
\hline Total nuclear families & 39.8 & 44.1 & 40.6 \\
\hline \multicolumn{4}{|l|}{ 6. Women alone } \\
\hline no male relative & 7.7 & 6.9 & 6.1 \\
\hline 7. Men alone & 0.6 & 1.9 & 0.8 \\
\hline Total number of families & 327 & 419 & 493 \\
\hline \multicolumn{4}{|l|}{ Percent families with no } \\
\hline adult men in Sugao $(3+5+6)$ & $23 \%$ & $26 \%$ & $26 \%$ \\
\hline
\end{tabular}


TABLE: 3 Earning members from Sugao migrants

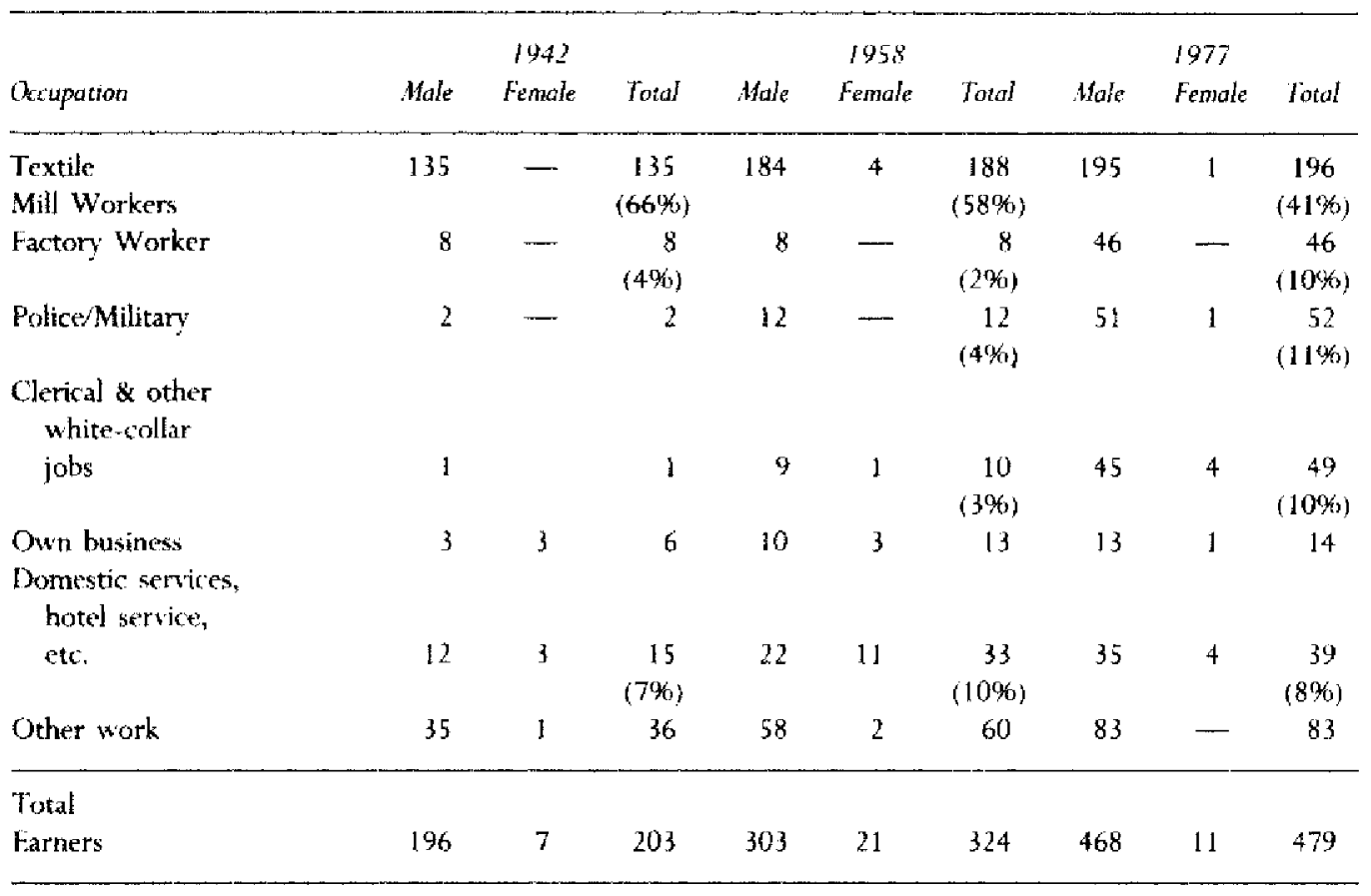

women are in this business. Generally these 'good' women are those who have men from their immediate or extended family supporting and helping them in the running of the business. In these cases the khanaval work is seen as a not particularly desirable (but acceptable on economic grounds) extension of these women's traditional roles of providing meals for their family men. Those women who are 'spoiled', and whose character and morality are dubious according to these commonly held standards, are the women who start and manage such businesses without 'legitimate' support from men who are related to them in the extended family. These women are perceived to be 'too free', due to the interaction necessitated by the business, with men who are unrelated to them and they are, by implication, free with sexual favours and morally 'loose'. Such prejudices leave a woman who has been bereft of traditional support structures in the unenviable position of being socially condemned whatever action she chooses to take. Ironically, women who are sheltered and in a secure niche in the village, family and societal structure do perceive this as a dilemma for the women so caught, but they are the most vociferous in their condemnation of women who stray from the traditional paths.

\section{Work in the Village}

The growth of textile mills and other activities resulting in new jobs in Bombay have caused changes in the life and work of women remaining behind in Sugao village. The availability of jobs in Bombay has resulted in continuing departures of adult males from Sugao. In 1977 almost 50 per cent of the adult males (468 out of 985) had left for work, mainly to Bombay, 
leaving their families behind in Sugao. Although these men come home to the village, one to four times a year, they spend most of their working lives away from their families. 'The percentage of families with no adult male living in the village has ranged from $23-26$ per cent (Table 2). Thus, since 1942, there have been a significant number of familics in Sugao without a resident male head of the household.

An increasing proportion of the population that remains in the village is thus female, and women do more of the work involved in daily farming. This, however, has resulted in very few changes in the position and status of Sugao women and few increases in their control over general decision-making or expenditure of family assets. Although 26 per cent of Sugao farms were cultivated predominantly by women in 1977 , and 75 per cent of those working as agricultural labourers in Sugao were women, it appears that management decisions remain a male prerogative, e.g. choice of inputs (like fertiliser) and choice of technology (such as whether to use bullocks or a tractor for ploughing the field or transporting the products to market). This phenomenon is significant and somewhat paradoxical-women doing more of the agricultural work in the village, but having as limited control as before. It deserves further investigation.

\section{WOMLN IN AGRICULTURIE IN SLGGAO}

A number of women were interviewed, including some who were cultivating alone and others who farmed on family lands. ${ }^{9}$ They stated that management decisions regarding the farm and also the family continue to be predominantly made by the men of Sugao. The male head of the family either returns from the city at critical junctures in the agricultural cycle or makes prior provision for tasks to be done and decisions to be made at these times. A male relative living in the village is sometimes delcgated the authority to make these decisions. In some of the families that own larger amounts of land, the older, senior women do supervise the daily work of farm labourers. However, when wages are paid at the end of the day, whether in cash or a share of the crop, a man from the family usually comes to the field to oversee the payments. Women do the tedious work of daily supervision, but men wield the power of paying the workers. By and large, women said that they made few of the decisions pertaining to the family farm. This lack of experience in management skills is a great handicap to a woman who inherits land, because she falls easy prey to male farmers interested in acquiring her property.

OWNERSHIP OF 1.ANIY RY SUGAO WOMEN

Although women now are legally entitled to inherit land, in practice land is predominantly inherited by males of the family. In Sugao, the sentiment is that Sugao land has to stay in Sugao hands. Women married to Sugao men are considered outsiders, for they generally come from families outside the village. The fact is a particular characteristic of Sugao, where 55 per cent of village families belong to two Maratha families who do not intermarry among themselves. ${ }^{10}$ For similar reasons, members of the other castes in Sugao must also seek mates outside the village. As a result, daughters of Sugao families are considered outsiders because they will be married to men from other villages. Wives are outsiders if they have no sons because Sugao men fear that if widowed they may allow Sugao land to be inherited by their relatives from other villages.

In this way all Sugao women are in some sense effectively considered outsiders and 
inheritance of Sugao lands by them is discouraged. This is reflected in the fact that in 1977 less than three per cent of Sugao lands was owned by women. Most of these inheritances occurred when women were widowed who had no sons to inherit the land. Even in these cases this land, legally owned by women, is mostly managed by men in the village from the extended family. Women who do try to till their own land are often very insecure and find it difficult; not only do they lack management skills but they are excluded from the male grapevine where farm practices and problems are discussed. This is still the most important information-disseminating system despite government-sponsored radio programmes about farm matters, market prices, and agricultural extension efforts. Women are not acculturated to listening to the radio for information. In fact, only the more aware and educated of the men use the radio for this purpose. Women are not invited even to the low level of agricultural extension work one observes in the village.

One extremely entcrprising farmer, a widow who is exceptional in her ability to manage, has effectively overcome this difficulty. She sends her young son to listen to the men's gossip in the village square of an evening and has him report back to her. She also learns new techniques and methods by very close observation of the innovative farmers in the village. Why don't other women who farm alone follow her example? Granted she is unusually intelligent and able; the social constraints operating against women discouragte all but the most determined.

If a woman does exert herself, takes on more decision-making and responsibilitics of management, the village society and her family do not excuse her from performing all the other tasks that she routinely must perform, work that is traditional to her role and status in the women's hierarchy. Not only are there no incentives to being enterprising but there are quite substantial tisincentives. A woman may be chastised and stigmatised for being 'too forward' or of 'loose morals' because she is felt to be too free in her conversations with men. If her husband is in Bombay, this gossip will inevitably reach him and she may find her position in her family, the most important structure for her security, undermined. Small wonder then that few women wish to play this little-gain high-loss game, unless they in fact own and control substantial resources including land. Generally women own very small parcels of land. In fact, all but three of the thirty pieces of land that were owned by women in Sugao were less than two acres in extent.

The economic imperative to perpetuate a family's ownership of the land, the major productive resource in the village, in combination with the patriarchal social system, operate effectively to keep women from acquiring property rights. Coupled with cultural norms that limit a woman's ability to manage this resource, this prevents her from acquiring decisionmaking roles regarding land and its cultivation in the village. On the other hand, women continue to maintain and nurture the family at a certain subsistence level, and provide the security and continuity that allows the peasant agriculture and the peasant family mode to persist and the men to migrate and work in Bombay in the textile mills.

WOMEN LABOURERS IN AGRICULTURE:

Women from families that practice subsistence farming and own sufticient land to support the family work primarily on their own farms but those with insufficient land to support the family work as agricultural labourers on others' lands. Those with practically no land such as the neo-Buddhists work almost exclusively as agricultural labourers. ${ }^{1:}$ 
In 1977 Sugao women accounted for 75 per cent of the total Sugao population claiming agricultural labour as their primary occupation. At that time women labourers were paid two thirds the wages of men. This ratio had persisted at least since 1942. In addition, because work was available for more days of the year for men ( 150 days as compared to 120 for women), these rates in fact averaged out to one rupee per day for women and two rupees per day for men. The discrepancy between wages for men and those for women has been increased as fewer and fewer men are left in the village who are available for casual day labour. In 1982, because of this scarcity of malc labour at peak demand periods in the agricultural cycle, men received seven to ten rupees, generally ten rupees, per day for farm labour while women received only three rupees for a day's work.

Thus the availability of and access to outside jobs for men, such as in Bombay's textile industries have improved their carning capacity outside and within the village. In contrast to this, Sugao women's lack of access to jobs in the formal sector of the textile industry has resulted not only in stagnation, but in a decline in their earning capacities. Social and cultural attitudes about appropriate sexual roles have thus prevented village women from obtaining jobs created in the free market system, jobs that have enhanced men's earning capacity.

An argument often made is that women who work, even in the menial low-paying jobs such as agricultural labour, have more control both over the spending of money and over their personal behaviour and lifestyle. This position is not completely substantiated by the opinions of women who work as agricultural labourers in Sugao. Even the neo-Buddhist women, who do enjoy greater social interaction through their work and are therefore psychologically more fit to deal with the larger world than than their more sheltered, highercaste contemporaries, do not agree. A highly independent posture cannot be expected merely because they receive their wages cash-in-hand. Even when women do work as farm labourers (as in the neo-Buddhist community in Sugao) and are a major, and at times the sole, source of income for the family, they earn so little and have so little surplus that their sense of security is not signiticantly enhanced. Nor are they able to exercise much control over the spending of their earnings. Their daily wages are used immediately to meet their families' daily consumption needs, handed over in the evening to the grocer for that day's quota of grain and oil. If the woman does not work one day, the stove is often cold that night and the family goes hungry. Given her immediate accountability for her wages and their use for immediate consumption, the female labourer acquires little financial independence. She does not earn the necessary surplus needed to make financial investments.

OTHFR SPIERES OF CONIKOL AND RESPONSHBLIT'

The lack of control of land assets and any economic surplus generated from them is a major factor that prevents women from becoming entrepreneurs in most new, non-agricultural activities that arise in the village.

For reasons that have been documented elscwhere, traditional artisan activities in which women played significant roles have been diminishing in Sugao. The new businesses which have emerged in the village, such as cycle repair shops, flour mills, poultry and dairy industries, and electrical repair shops, are owned by men. There is only one woman entrepreneur in Sugao, an educated young woman, married into the village, who borrowed some money from her brother and started a small chili grinding business. In addition, she runs a small business sewing clothes for neighbours on a sewing machine, also acquired with 
financial help from her brother. Many women in Sugao own sewing machines and aspire to establish such a business but cannot because the market is saturated. Generally, most new businesses in Sugao are initiated and run by men while women have been displaced from the supportive roles that they played in traditional artisan attivities such as blanket-weaving and pottery. ${ }^{12}$

If women's daily routine in Sugao is examined, their work and social involvement outside the immediate family appear minimal. Men control the management of the farm and disposal of farm surplus. They purchase and distribute most of the consumer goods. Men living in Bombay send home, two or three times a year, packages containing consumer goods such as clothing, tea, sugar, cosmetic, and toys. In 1977 , seven per cent of families claimed that they received all their consumer goods from Bombay; an additional 13 per cent received about half; and seven per cent received from 10-25 per cent. These purchases, which are used by the women and children living in Sugao, are made by the men living in Bombay. Women can exercise little choice in this matter.

Even in Sugao, customarily the men go to the nearby market town of Wai to do the shopping. Rarely are women asked or expected to accompany the men to belp in selcction, even in matters as personal as the choice of saris bought once or twice a year for the women of the family.

Thus the fact that many Sugao men now live and work in Bombay has done little to incrcase Sugao women's opportunities for purchasing and marketing for the family. The old pattern in which men made most of the decisions has been adapted to the new conditions and they continue to make these decisions, with very little shifting of these powers to women. The social structure has accommodated, allowed men greater freedoms, including travel away for jobs, but offered few new options for women. Women continue in their closely circumscribed daily lives in Sugao andsustain the family.

\section{Sugao Women in Bombay}

One reason that Sugao women have not obtained nor even aspired to jobs in the Bombay textile industry is that the upper-caste Maratha men from whom the early migrants to Bombay were drawn, and who therefore had the contacts in Bombay to procure such jobs, did not consider it appropriate for women to work outside the house. A woman working for wages outside the home meant that the men in her family could not support her. As Boserup notes, ${ }^{13}$ in rural India there are four general types of female work patterns. In the top group of high-caste families, women take no part in outdoor activities. The next is the cultivator caste, in which women are occupied in largely domestic duties and never earn money to support the family, In the third group, women help men in the family farm and might work for wages in the peak season. In the fourth and lowest ranked group, the women work as field labourers and are expected to seek paid work for the support of their families. Fen today in Sugao, by and large, the social status aspired to is that of the wives of the richest landowners who do not work outside the family house. It is not surprising, therefore, that at the turn of the century and into the $1940 \mathrm{~s}$ and 1950 s factory work, entailing as it does independent activity outside the house, possibly under the supervision of men who are not members of the family, was not considered ideal work for Sugao women, and Sugao men did not even consider obtaining jobs in the textile mills for Sugao women. 
As a result, the earlier growth period of the textik industry in Bombay when Sugao men were increasingly joining the textile mills, Sugao women were not. Thus the industry provided a very direct ladder for upward job mobility for the men but not the women. Subsequently work for women in the Bombay textile industry declined. The departments in which women were recruited, such as the spinning and spindle winding sections, became more mechanised and women who were displaced from their jobs were not rehired in other departments of the factories. Thus the opportunity to obtain jobs in the textile mills became even more remote for the Sugao woman.

From Meera Savara's detailed case studies of two lower-caste neo-Buddhist women working in the Bombay textile industry and the themes developed from her interviews with some fifty other women workers, ${ }^{14}$ it appears that, despite having to face opposition from thcir families (particularly husbands who at times accused them of havingsexual relationships with other men at the factory), women cherished the freedom and opportunity the industrial jobs offered them. This spectre of being accused by husbands, brothers, and fathers- and mothers-in-law of sexually promiscuous behaviour is the bane of the working woman's life in India. It is the ultimate weapon used to undermine her determination to be independent and to justify physically abusing her.

Despite this, as Savara describes, women working in the mills greatly prefer their daily routine, beginning at $7.00 \mathrm{am}$ and consisting of monotonous and dull tasks, to the more restricted work of being a housewife. They value their opportunities to meet with women friends and co-workers, to talk, to walk home together, perhaps even to have a cup of tea at a restaurant. These are quite simple opportunities for the most basic social intercourse, but ones that are systematically denied women who are in more traditional family structures in both urban and rural contexts in India. There women are closely confined to their homes and tied up with family-related chores. By contrast, even the very limited freedom offered by work in the textile industry seems like an opportunity. Working women with the most menial jobs do not want to relinquish the opportunity to earn their own money and retain the security and independence the work provides them.

Denied the option to work in the mills, the one occupation that Sugao women do practice in Bombay is running khanavals. In 1977, five Sugao women were running khanavals, catering to Sugao men living in the same or nearby tenement. All five were engaged in this activity in 1982. Their day is long in this business, starting at 5.0 am and going almost without a break till 8.00 or $9.00 \mathrm{pm}^{1.5}$ Although this work does entail more contact and interaction with men, the routine necessitates that the woman spends most of the day within the confines of her $10^{\prime} \times 10^{\prime}$ tenement room where she eats, sleeps, cooks, cleans, and caters meals to sometimes 20-30 men. There are few opportunities for carefree interaction. But the work is considered low status: 'those women generally lack virtue and are too free with men' is the blanket statement heard in conversations with Sugao people. Yet it is the efforts of these women that enable the factory worker to enjoy home-cooked, relatively clean and unadulterated food at reasonable prices. The case studies from Sugao show that few women have succeeded in establishing these businesses alone without the overt support of legal relatives such as a husband or a brother-in-law or the more covert support of the male leaders from Sugao with whom they were involved.

Credit cooperatives for women have been started in other mill areas of Bombay. The efforts and experience of promoting these is documented in Savara's and Krishna Raj's 
work. ${ }^{16}$ The Sugao women, who run the khanaval businesses in the Lower Parel, Chinchpokli parts of Bombay's mills area have not heard about the credit union. Even if they had, since these women are from the high status Maratha caste, they have been to some extent sheitered and supported and to an equally great or greater extent, constrained and limited, by the family and extended village structure that reaches into the city. Some of the benefits Krishna Raj cites as accruing to women running khanavals from the cooperative credit society such as loans, budgeting and management help, prevention of undercutting, and default on payment of meals are enjoyed by the Sugao khanaval women by virtue of their contacts and relationships with Sugao men. Their clientele largely consists of Sugao men or their relatives, and money, support, and know-how is provided through established village networks. They are in fact working and living in a social microcosm of Sugao that happens to be located in the heart of Bombay. It therefore seems unlikely that Sugao women would very quickly join such unions or be vocal and active in them.

Krishna Raj recounts that the daughter-in-law of the vice president of the established credit union complained that her mother-in-law did 'too much' for the organisation and did not help her enough with the children or running their business. The vice president, however, is aware of the benefits gained through the credit union and enjoys the 'respect' working on it has brought her. The conflict between the gains derived from working outside the family and the resulting tensions created within it for a woman are clearly felt. None of the Sugao women running khanavals seems prepared to take up the challenge and the ensuing conflicts.

It is important to note that the women who run the khanaval business in Bombay's textile areas are providing a major support service to the industrial workers. These women receive little or no support for this activity from any formal institution, such as the mills themselves, banks, and other credit institutions. They have to garner the resources to provide themselves with housing, utensils, equipment and other physical items to start their enterprises. They conduct the business in over-crowded, congested tenement rooms in which they also eat, sleep, and recreate. Aside from seeing a couple of movies or making trips to the market, their lives are circumscribed by the four walls of their tiny tenement room. The textile industry in Bombay is currently in a troubled state. The prevailing strikes and lockouts, resulting in workers being out of work for long months, has meant that these women not only have had to keep prices of meals fixed, despite rising costs of foods, but also that they have had to carry some workers unable to pay. Part of the burden of the strike falls on the backs of these women, but their contribution is taken for granted and unacknowledged.

This paper has limited itself to the subject of the impact of the textile industry on Sugao women and their work. It has not addressed the complex question of the fate of the Bombay textile industry, currently in flux and under stress. The long term outcomes of the 1982 strike in the Bombay textile industry will in general have profound complications for the work and viability of the whole Sugao village economy and in particular on the work and viability of these women's businesses. If the status quo cannot be maintained and the fragile family societal network that at the same time supports and fetters these women becomes defunct, then, and only then, Sugao khanaval women, and others like them, may in fact be effectively mobilised to join outside sources such as cooperative credit societies for mutual support and help. 


\section{Conclusion}

As long as the family and caste structure of Sugao society extends both a set of constraints to women's roles outside the family and support for those traditionally sanctioned activities that occur within the family, women's lives and roles are not going to be greatly influenced and changed by Bombay's textile industries. Dramatic changes and greater freedom for action will result only when caste and family influences are necessarily reduced by economic realities outside the control of Sugao villagers. So far there has been little impetus for this to emanate from the textile industry, an indenstry which has changed the lives of Sugao men.

\section{NOTHS AND REHERFNCHS}

$1 \mathrm{By} 1879$, of the 56 spiming and weaving mills, three quarters were in Bombay Presidency and more than half on Bombay isiand itself. See (Gadgil, 1). R., The hidustrul Froluton of Inda in Recent Times 1560-1939, 5th Edition, Bombay, Oxford University Press, 1971, pp, 54-56, 75-77, 104-108, 254-261, 327

2 te Patel, Kunj, Rural Lahor in industrai Bombar, Botnlay, Popular Prakashan, 1963, pp. 4-8. In a 1957 survey (1. 6) of textile labour force in Bombay, 45 per cent came from the Konkan and almost 30 per cent from the [recon (where sugao is located)

3 Nigel Harris in tonomk Devoloment. Cues and Plonnng: The Case of Rombas, Bombay, Oxford University Press, 1978, sas that Bombay trolay incoporates clements of two economic periods, ninteenth-century textiles and twentie th-' 'cntury petro-chemicals page 1 !. 'The textile industry, employing 23 per cent of the capital and 48 per cent of the labour force in greater Bombay's indistry, is still of decisive importance for the city. It indirectly continut's to attract a sustaind flow of new wokkers into certain heavily populated districts (p. 81)

4 Data for this paper were drawn from seceral surveys cxecuted by the Gokhale Institute of Polities and fonomics, poona, since 19.36, particularly two comprehensive socto-economic full census surveys in 1942-43 and 1958-59. Components of these were repeated by the author in a full crnsus survey of rillage resiclents in 1976-77 during an 18-month residence and tield investigation of the village. A purposice sample of Bombay migrants was intensively interviewed by the author during the following three month period. 'The study was augmented by observations and information collected by the author during two subsequent visits both to the village and to Bombay to interview Sugan migrants in the summer of 1979 and December-January, 1981-82.

5 Annecdotal information on families who had sonze nembers living in Bombay during the early 1900s was collected by Gokhale [nstitute field workers in the $1930 \mathrm{~s}$. Case studies indicate that some of the families who are now well-to-rlo gained an economic edge as a result of this carly migration

6. This caste selection sectos to have been typical ter textile Jabour recruitment in Bombay, Kunj Patel, op. (it., notes that in her survey of 500 workers from the Konkan almost 63 per cent were Maratha (p. 43). Caste remains an imprortant tactor affecting an individual's life in village India. Its influence permeates most interactions and affects people's opportumities atal decisions. The Siggzo village population is dominated by the Maratha caste (70 per (cont in the 1977 population), The caste compesition of the sillage, for 1942, 1958, and 1977, given in Table 1 , listed by the locally accepted status hicrachy, shows that it has remaibed fairlv constant over the years. The four major caste groups in the village are the Marathas, Dhangars (weavets), neo-Buddhist (tormerly Mahars and considered untouclable), and a mixture of artisan castes

7 The joint or extended family in which married sons live with their wives and children in the same housethold as their parents is still the prevailing family structure in Sugao, as ittustrated in Table 2 which shows over 52 per cent of 1977 sugao families to be joint

8 Unpublished notes, 1942 and 1958, M. B. Jagtap, Gokhale Institute of Politics and Economics, Poona, ladia

9 Detaled case studies of women in Sugao were compiled by the author during residence in Sugao in $1976-$ 77,1979 and 1981-82. The author is in the process of completing a book on the impact of development on rural women in India

10 The two main families of Sugao, the Yadavs and the jadbars belong to the same devak group and as such marriage between them is not permitted 
11 The neo-Budk hists of Sugae are the caste formerly known as Mahars and considered untouchable. Although the Mahars were not the only caste considered untouchable in the community they suftered the most because they were obliged to work as village servarts. In 1957 the Mahar conmunity, under the leadership of Dr. Ambedkar revolted against the Hindu religion and in order to escape the curse of untouchability adopted Budhism. The tillage community has not fully accepted this distinction. The Mahars continue to live segregated in the village in an area know as Mahar wada and are easily distinguished from other Buddhists by the term neo-Burdhist

12 For the comparison of rural industries in one small (Sugao) and one large village in Maharashtra, se

Dandekar, Hemalata and Sulabha Brahme, 'Role of Rural Industries in Rural Development' in Misra, R. P. and K. V. Sundaram, Rural Area Development, New Delhi, Sterling Publishers, 1979, pp. 122-143

13 See Boserup, Ester, Women's Role in Econonic Detelopment, New York, St Martin's Press, 1970, pp. 69-75, $108-115$

14 See Sayara, Meera, Working Class Women liew Their Own Lives, Bombay, Research Monograph, Institute of Social Research and Education, Pp. 19-30

15 See Dandekar, Hemalata, Rural Development: Lessons from a Villoge in Decan Maharashtra, Ph[) dissertation, University of California, Los Angeles, 1978, Pp. 255-257 for case studics

16 Ser Savara, Meera, Organinng Women in the Informal Sector-A Case Study of the Annopurna's in hidia, Mimeograph, Bombay, Feminist Resource Center, 1981; and Krishna Raj, Maithrevi, Approaches to Self-Reliance for Women Some Urbun Models, Bombay, SNDT Women's University, 1980, pp. 35-45 